\title{
Effect of Enriched Composts on Rhizosphere Soil Enzymatic Activity of Soybean in Vertisols
}

\author{
Ashay D. Souza", P.W. Deshmukh and S.M. Bhoyar \\ Department of Soil Science and Agricultural Chemistry, Dr. Panjabrao Deshmukh Krishi \\ Vidyapeeth, Akola, Maharashtra, India \\ *Corresponding author
}

\section{A B S T R A C T}

\begin{tabular}{|c|c|}
\hline Keywol & \multirow{7}{*}{$\begin{array}{l}\text { Field experiment was conducted to evaluate effect of enriched composts on rhizosphere } \\
\text { soil enzymatic activity of soybean in vertisols. The experiment was laid out in RBD with } \\
\text { eight treatment replicated thrice. The enriched composts like Phosphocompost having } 0.80 \\
\mathrm{~N}, 1.65 \mathrm{P}, 0.68 \mathrm{~K}, 0.39 \mathrm{~S}, \mathrm{C}: \mathrm{N} \text { ratio of } 20.44 \text { and Nitrophospho-Sulphocompost having } \\
1.85 \mathrm{~N}, 1.76 \mathrm{P}, 0.92 \mathrm{~K}, 1.58 \mathrm{~S}, \mathrm{C}: \mathrm{N} \text { ratio of } 19.30 \text { was used. Results indicated that the soil } \\
\text { enzymatic activity at flowering and pod formation stage i.e Dehydrogenase ( } 41.96 \text { and } \\
\left.46.29 \mu \mathrm{g} \text { TPF g-1 } 24 \mathrm{hr}^{-1}\right) \text {, Alkaline phosphatase }(161.34 \text { and } 163.09 \mu \mathrm{g} \text { p-nitrophenol g } \\
\left.24 \mathrm{hr}^{-1}\right) \text {, Aryl sulphatase }\left(42.16 \mathrm{and}^{-1} 6.59 \mu \mathrm{g} \mathrm{p} \text {-nitrophenol } \mathrm{g}^{-1} 24 \mathrm{hr}^{-1}\right) \text { and Urease activity } \\
\left(55.60 \text { and } 56.86 \mathrm{mg} \mathrm{NH}_{4}-\mathrm{N} \mathrm{g}^{-1} 24 \mathrm{hr}^{-1}\right) \text { was significantly highest in } 100 \% \mathrm{P} \text { through } \\
\text { Nitrophospho-sulpho compost followed by } 100 \% \mathrm{P} \text { through Phospho-compost over all } \\
\text { other treatments. Hence application of organics increases soil biological properties and } \\
\text { yield of crop. }\end{array}$} \\
\hline & \\
\hline & \\
\hline & \\
\hline & \\
\hline Article Info & \\
\hline & \\
\hline
\end{tabular}

\section{Introduction}

The soil is home to a large proportion of the world's biodiversity. In balanced soil, plants grow in an active and steady environment. The mineral content of the soil and its heartiful structure are important for their wellbeing, but it is life in earth that powers its cycles and provides its fertility.

Without the activities of soil organisms, organic materials would accumulate and litter the soil surface, and there would be no food for plants. The soil biota includes: moles, rabbits and rodents, woodlice, earthworm, beetles, centipedes, slugs, snails, ants, yeasts, bacteria (commonly actinobacteria), fungi, protozoa, roundworms and rotifers.
Of these, bacteria and fungi play roles in maintaining a healthy soil they act as decomposers that break down organic materials to produce detritus and other breakdown products.

Soil enzymes release nutrients into the soil by means of organic matter degradation, helps in the Identification of soils, used for the Identification of microbial activity, they are sensitive indicators of ecological change. These enzymes may include amylase, arylsulphatases, $\quad \beta$-glucosidase, cellulose, chitinase, dehydrogenase, phosphatase, protease, and urease released from plants. (Miwa et al., 1937). 
Dehydrogenase activity and SMBC was considerably reduced with increase in soil salinity and alkalinity, while these parameters increased with organic carbon content of this soil. Soil urease, phosphatase, dehydrogenase, invertase, cellulase and arylsulphatase activity being related to some important N, P, S and C reaction, respectively. Nannipiery et al., (1983) showed that, at the end of incubation enzyme activities(DHA, Urease) were little higher except for soil phosphatase in amended soil than those in the unamended soil. Dehyrogenase is considered to play an important role in the initial stage of the oxidation of soil organic matter (Ross, 1971) by transferring hydrogen and electron from substrate to acceptors

Enzymes are the direct mediators for biological catabolism of soil organic and mineral components.

Thus, these catalysts provide a meaningful assessment of reaction rates for important soil processes. Soil enzyme activity is often closely related to soil organic matter, soil physical properties and microbial activity. Changes much sooner than other parameter, thus providing early indication of soil health. In addition, soil enzyme activities can be used as measure of microbial activity, soil productivity and inhibiting effects of pollutants (Tate, 1995).

\section{Materials and Methods}

The present investigation was undertaken at Research Farm of Department of Soil Science and Agricultural Chemistry, Dr. Panjabrao Deshmukh Krishi Vidyapeeth, Akola during Kharif season of 2016-17 in randomized block design with eight treatments replicated thrice. The treatment were $\mathrm{T}_{1}-$ Control, $\mathrm{T}_{2}$ $100 \%$ RDF, $\mathrm{T}_{3}-50 \% \quad \mathrm{P}$ through $\mathrm{PC}$ +Remaining RDF through chemical Fertilizers, $\mathrm{T}_{4}-25 \% \quad \mathrm{P}$ through NPS
+Remaining RDF through chemical Fertilizers, $\quad \mathrm{T}_{5}-50 \% \quad \mathrm{P}$ through NPS +Remaining RDF through chemical Fertilizers, $\mathrm{T}_{6}-25 \% \quad \mathrm{P}$ through NPS +Remaining RDF through chemical Fertilizer, $\mathrm{T}_{7}-100 \% \mathrm{P}$ through $\mathrm{PC}, \mathrm{T}_{8}-100 \% \mathrm{P}$ through NPS. Where PC refers to Phospho compost, NPS refers to Nitrophospho-Sulpho compost and RDF for Recommend Dose of fertilizer. The experimental soil was developed on basaltic platue on plain land and classified under Vertisols.

Phospho-compost or N-enriched phosphocompost technology has been developed using phosphate solubilising microorganisms, namely, Aspergillus awamori, Pseudomonas striata and Bacillus megaterium, phosphate rock, pyrite and bio-solids to increase the manurial value as compared to ordinary FYM.

Nitrophospho-sulpho compost is prepared using crop residues, urea, gypsum, rock phosphate. The nitrophospho-sulpho compost will be prepared by decomposing crop residues viz., Wheat straw and shredded cotton stalk with rock phosphate, urea and gypsum.

The rhizospheric soil sample were collected at flowering and pod formation stage of the crop and stored carefully at $4^{\circ} \mathrm{C}$ for biological study and air dried in shade and processed for further analysis.

Urea, Diammonium phosphate, Muriate of potash alone and also in combination with organic manures i.e., Phospho-Compost and Nitrophospho-Sulpho compost were applied. Treatment wise basal dose of fertilizers were applied at the time of sowing. The enriched compost was applied 15 days before sowing of crop. The nutrient content of enriched composts i.e., Phospho compost and nitrophospho-sulpho compost is presented in table 1 . 


\section{Results and Discussion}

Effect of enriched composts on
productivity of soybean

The significantly higher grain yield of soybean was recorded by the application of $100 \% \mathrm{P}$ through NPS (27.90 $\left.\mathrm{q} \mathrm{ha}^{-1}\right)$, followed by the treatment of application of $100 \% \mathrm{P}$ through NPS (27.83 q ha ${ }^{-1}$ ), However the yield obtained by both this treatment were statistically at par.

Significantly highest straw yield of soybean was obtained in the treatment of application of $100 \% \mathrm{P}$ through NPS $\left(43.67 \mathrm{q} \mathrm{ha} \mathrm{h}^{-1}\right)$ followed by treatment with application of $50 \%$ P through NPS (42.20 q ha ${ }^{-1}$ ), However the yield obtained by both these treatments were statistically at par.

The higher soybean grain and straw yield received by the $100 \%$ application of both the enriched composts may be due to full compensation of required nutrients to the crop, as well as the mansoon season during 2016-17 was also satisfactory.

Role of enriched composts on soil enzymatic activity in soybean

\section{Effect on Dehydrogenase Activity (DHA)}

The Dehydrogenous activity of the soil as influenced by various treatment of is presented in table 3 showed the rhizosphere soil at flowering stage was ranged from 30.99 to $41.96 \mu \mathrm{g} \mathrm{TPF} \mathrm{g}^{-1} 24 \mathrm{hr}^{-1}$. Dehydrogenous enzyme activity significantly increased in the treatment of $100 \% \mathrm{P}$ through nitrophosphosulpho compost and phospho-compost over all other treatments (41.98 and $40.84 \mu \mathrm{g}$ TPF $\mathrm{g}^{-1} 24 \mathrm{hr}^{-1}$ ) which were at par with each other.

Dehyrogenase enzyme during soybean pod formation stage is depicted in table 3 , which shows increase in enzyme activity from lowest to highest from 33.12 to $46.29 \mu \mathrm{g}$ TPF $\mathrm{g}^{-1} 24 \mathrm{hr}^{-1}$. Significantly highest yield was found in treatment with $100 \% \mathrm{P}$ through nitro phospho- sulpho compost i.e., $46.29 \mu \mathrm{g}^{-1}$ TPF $\mathrm{g}^{-1} 24 \mathrm{hr}^{-1}$ next to $100 \% \mathrm{P}$ through phospho-compost i.e., $44 \mu \mathrm{g}^{-1} \mathrm{TPF} \mathrm{g}^{-1} 24 \mathrm{hr}^{-1}$. Both treatments were found to be significant at par with each other. The dehydrogenase activity with application of $25 \%$ and $50 \%$ of enriched composts and 100\% RDF are found to be at par with each other, the significantly lowest enzyme activity was found with control plot (33.12 $\mu \mathrm{g}^{-1}$ TPF g $\left.{ }^{-1} 24 \mathrm{hr}^{-1}\right)$

This increase in Dehydrogenous activity may be due to the application of organic manure which results in more microbial activity. The significantly lowest Dehydrogenous activity was found in the treatment where no fertilizers were applied. Similar result was found by Bedi et al., (2009).

\section{Effect on alkaline phosphatase activity}

The alkaline phosphatase activity at different stage of soybean crop growth is shown in table 4. During the flowering stage the enzyme activity showed significantly highest activity of $161.34 \mu \mathrm{g}$ p-nitro phenol g-1 $24 \mathrm{hr}^{-1}$. With application of $100 \% \mathrm{P}$ through NPS followed by application of $100 \% \mathrm{P}$ through PC $\left(156.31 \mu \mathrm{g}\right.$ p-nitro phenol g $\left.{ }^{-1} 24 \mathrm{hr}^{-1}\right)$.

Alkaline Phosphatase activity with application of $25 \%$ and $50 \% \mathrm{P}$ through enriched composts and 100\% RDF were at par with all other treatments. The significantly lowest enzyme activity of $136.63 \mu \mathrm{g}$ p-nitro phenol $\mathrm{g}^{-1} \quad 24 \mathrm{hr}^{-1}$ was found without application of any source of nutrients.

During the soybean pod formation stage the alkaline phosphatase activity varied from 138.84 to $163.09 \mu \mathrm{g}$ p-nitro phenol g${ }^{-1} 24 \mathrm{hr}^{-1}$. The highest activity was found with $100 \% \mathrm{P}$ 
through NPS (163.09 $\mu \mathrm{g}$ p-nitro phenol $\mathrm{g}^{-1}$ $24 \mathrm{hr}^{-1}$ ) which is followed by application of $100 \% \mathrm{P}$ through PC (157.62 $\mu \mathrm{g}$ p-nitro phenol g ${ }^{-1} 24 \mathrm{hr}^{-1}$ ).

Application of $100 \% \mathrm{P}$ through PC, $25 \% \mathrm{P}$ through PC and NPS, 50\% P through PC and NPS and $100 \%$ RDF treated units are statistically at par with each other. Lowest alkaline Phosphatase at pod formation was with control plot with $138.84 \mu \mathrm{g}$ p-nitro phenol $\mathrm{g}^{-1} 24 \mathrm{hr}^{-1}$ enzyme activity.
The results indicated that soil organic matter content and soil microbial activities are vital for nutrient turnover and productivity of soil. The results are in conformity with findings of Kachikerimeth and Dhyan Singh (2001) who reported organics and balanced nutrition increased the alkaline phosphatase activities. The significantly higher activities of alkaline phosphatase in organically treated soil may be due to enhanced microbial activity and diversity of phosphate solubilising bacteria (Mandal et al., 2007).

Table.1 The nutrient content of enriched composts

\begin{tabular}{|l|c|c|c|c|c|}
\hline Organics & N & P & K & S & C:N \\
\hline Phosphocompost & 0.80 & 1.65 & 0.68 & 0.39 & 20.44 \\
\hline Nitro phospho Sulpho compost & 1.85 & 1.76 & 0.92 & 1.58 & 19.30 \\
\hline
\end{tabular}

Table.2 Effect of enriched composts on productivity of soybean

\begin{tabular}{|c|l|c|c|}
\hline & & \multicolumn{2}{|c|}{ Tield $\left(\mathrm{q} \mathrm{ha}^{-1}\right)$} \\
\cline { 3 - 4 } & & Grain & Straw \\
\hline$T_{1}$ & Control & 21.43 & 32.15 \\
\hline$T_{2}$ & $100 \%$ RDF & 24.58 & 36.67 \\
\hline$T_{3}$ & $50 \%$ P through PC + Remaining through fertilizer & 25.14 & 37.71 \\
\hline$T_{4}$ & 25\%P through PC+ Remaining through fertilizer & 24.58 & 36.87 \\
\hline$T_{5}$ & $50 \%$ P through NPS + Remaining through fertilizer & 26.13 & 41.75 \\
\hline$T_{6}$ & 25\% P through NPS+ Remaining through fertilizer & 25.36 & 38.04 \\
\hline$T_{7}$ & $100 \%$ P through PC & 27.83 & 42.20 \\
\hline$T_{8}$ & $100 \%$ P through NPS & 27.90 & 43.67 \\
\hline & $S E(m) \pm$ & 1.25 & 1.93 \\
\hline & $C D$ at $5 \%$ & 3.77 & 5.83 \\
\hline
\end{tabular}

Table.3 Effect of different treatments on dehydrogenase activity at flowering and pod formation stage

\begin{tabular}{|c|l|c|c|}
\hline \multirow{2}{*}{ Treatments } & \multicolumn{2}{c|}{ DHA $\left(\mu \mathrm{g} \mathrm{TPF}^{-1} 24 \mathrm{hr}^{-1}\right)$} \\
\cline { 3 - 4 } & & Flowering stage & Pod formation stage \\
\hline $\mathrm{T}_{1}$ & Control & 30.99 & 33.12 \\
\hline $\mathrm{T}_{2}$ & $100 \%$ RDF & 34.64 & 35.00 \\
\hline $\mathrm{T}_{3}$ & $50 \%$ P through PC + Remaining P through fertilizers & 35.04 & 35.13 \\
\hline $\mathrm{T}_{4}$ & 25\% P through PC + Remaining P through fertilizer & 35.55 & 36.21 \\
\hline $\mathrm{T}_{5}$ & $50 \%$ P through NPS + Remaining P through fertilizer & 37.67 & 42.04 \\
\hline $\mathrm{T}_{6}$ & 25\% P through NPS + Remaining P through fertilizer & 32.86 & 33.75 \\
\hline $\mathrm{T}_{7}$ & $100 \%$ P through PC & 40.84 & 44.00 \\
\hline $\mathrm{T}_{8}$ & $100 \%$ P through NPS & 41.96 & 46.29 \\
\hline & SE(m) \pm & $\mathbf{0 . 9 8}$ & $\mathbf{1 . 2 0}$ \\
\hline & CD at 5\% & $\mathbf{2 . 9 7}$ & $\mathbf{3 . 6 4}$ \\
\hline
\end{tabular}


Table.4 Effect of different treatments on alkaline phosphatase activity at flowering and pod formation stage

\begin{tabular}{|c|l|c|c|}
\hline \multirow{2}{*}{} & \multicolumn{2}{|c|}{ Treatments } & \multicolumn{2}{c|}{$\begin{array}{c}\text { Alkaline Phosphatase activity } \\
\left(\mu \mathrm{g} \mathrm{p} \text {-nitro phenol released } \mathrm{g}^{-1} 24 \mathrm{hr}^{-1}\right)\end{array}$} \\
\cline { 3 - 4 } & & 136.63 & Pod formation stage \\
\hline $\mathrm{T}_{1}$ & Control & 137.09 & 138.84 \\
\hline $\mathrm{T}_{2}$ & $100 \%$ RDF & 135.01 & 139.73 \\
\hline $\mathrm{T}_{3}$ & $50 \%$ P through PC + Remaining P through fertilizers & 141.76 & 137.01 \\
\hline $\mathrm{T}_{4}$ & $25 \%$ P through PC + Remaining P through fertilizer & 151.86 & 145.56 \\
\hline $\mathrm{T}_{5}$ & $50 \%$ P through NPS + Remaining P through fertilizer & 146.88 & 153.60 \\
\hline $\mathrm{T}_{6}$ & $25 \%$ P through NPS + Remaining P through fertilizer & 156.31 & 150.93 \\
\hline $\mathrm{T}_{7}$ & $100 \%$ P through PC & 161.34 & 157.62 \\
\hline $\mathrm{T}_{8}$ & $100 \%$ P through NPS & $\mathbf{0 . 8 8}$ & 163.09 \\
\hline & SE(m) \pm & $\mathbf{2 . 6 8}$ & $\mathbf{1 . 0 4}$ \\
\hline & CD at $5 \%$ & & $\mathbf{3 . 1 6}$ \\
\hline
\end{tabular}

Table.5 Effect of different treatments on urease enzyme activity at flowering and pod formation stage

\begin{tabular}{|c|l|c|c|}
\hline \multirow{2}{*}{} & \multirow{2}{*}{ Treatments } & \multicolumn{2}{|c|}{$\begin{array}{c}\text { Urease activity } \\
\left(\mathrm{mg} \mathrm{NH}_{4}-\mathrm{N} \text { released } \mathrm{g}^{-1} \text { soil } 24 \mathrm{hr}^{-1}\right)\end{array}$} \\
\cline { 3 - 4 } & & Flowering stage & Pod formation stage \\
\hline $\mathrm{T}_{1}$ & Control & 33.80 & 36.55 \\
\hline $\mathrm{T}_{2}$ & $100 \%$ RDF & 40.20 & 42.15 \\
\hline $\mathrm{T}_{3}$ & $50 \%$ P through PC + Remaining P through fertilizers & 43.72 & 45.72 \\
\hline $\mathrm{T}_{4}$ & $25 \%$ P through PC + Remaining P through fertilizer & 42.22 & 44.27 \\
\hline $\mathrm{T}_{5}$ & $50 \%$ P through NPS + Remaining P through fertilizer & 40.88 & 42.98 \\
\hline $\mathrm{T}_{6}$ & $25 \%$ P through NPS + Remaining P through fertilizer & 50.70 & 51.40 \\
\hline $\mathrm{T}_{7}$ & $100 \%$ P through PC & 51.89 & 52.78 \\
\hline $\mathrm{T}_{8}$ & $100 \%$ P through NPS & 55.60 & 56.86 \\
\hline & SE(m) \pm & $\mathbf{1 . 2 9}$ & $\mathbf{1 . 5 1}$ \\
\hline & CD at $5 \%$ & $\mathbf{3 . 9 0}$ & $\mathbf{4 . 5 6}$ \\
\hline
\end{tabular}

\section{Effect on aryl sulphatase activity}

Aryl sulphatase activity (Table 4) at flowering stage of soybean crop shows lowest to highest values of 23.37 to $42.16 \mu \mathrm{g}$ p-nitro phenol $\mathrm{g}^{-1}$ $24 \mathrm{hr}^{-1}$ The highest enzyme activity is shown in treatment $\mathrm{T}_{8}$ with application of $100 \% \mathrm{P}$ through Nitrophospho-sulpho compost (42.16 $\mu \mathrm{g}$ p-nitro phenol released $\mathrm{g}^{-1} 24 \mathrm{hr}^{-1}$ ) followed by treatment with $100 \% \mathrm{P}$ through phospho compost which are at par with each other.

Aryl sulphase activity with $25 \%$ and $50 \% \mathrm{P}$ through PC and NPS and 100\% RDF treated treatment were at par with each other.
However the lowest enzyme activity is seen in control unit $(23.37 \mu \mathrm{g}$ p-nitro phenol released $\left.\mathrm{g}^{-1} 24 \mathrm{hr}^{-1}\right)$.

Aryl sulphatase activity at flowering stage is found to range from 25.24 to $46.59 \mu \mathrm{g} \mathrm{p}$ nitro phenol released $\mathrm{g}^{-1} 24 \mathrm{hr}^{-1}$. Application of $100 \% \mathrm{P}$ through NPS showed highest enzyme activity $(46.59 \mu \mathrm{g}$ p-nitro phenol released $\mathrm{g}^{-1} 24 \mathrm{hr}^{-1}$ ) followed by application of $100 \% \mathrm{P}$ through PC $(44.46 \mu \mathrm{g}$ p-nitro phenol released $\left.\mathrm{g}^{-1} 24 \mathrm{hr}^{-1}\right)$. The lowest activity was noticed with plot without application of fertilizer or manure $(25.24 \mu \mathrm{g}$ p-nitro phenol released $\mathrm{g}^{-1} 24 \mathrm{hr}^{-1}$ ) which is at par with all other treatments. 
The results showed highest enzyme activity with application of organics in form of composts, similar results were obtained by Vong et al., (2003) and Thaware et al., (2016) where the application of organic source like crop residue stalk and organic manure showed highest enzyme activity than control.

\section{Effect on urease activity}

The Urease activity at different stage of soybean crop growth is shown in table 5 . During the flowering stage the enzyme activity is increased from smallest to biggest value from 33.80 to $55.60 \mathrm{mg} \mathrm{NH}_{4}-\mathrm{N} \mathrm{g}^{-1}$ soil $24 \mathrm{hr}^{-1}$.

The significantly highest activity of $55.60 \mathrm{mg}$ $\mathrm{NH}_{4}-\mathrm{N} \mathrm{g}^{-1}$ soil $24 \mathrm{hr}^{-1}$ was found with application of $100 \% \mathrm{P}$ through NPS followed by application of $100 \% \mathrm{P}$ through PC (51.89 mg $\mathrm{NH}_{4}-\mathrm{N} \mathrm{g}^{-1}$ soil $24 \mathrm{hr}^{-1)}$ which are at par with each other.

Urease activity with application of $25 \%$ and $50 \% \mathrm{P}$ through enriched composts and 100\% RDF were at par with all other treatments. The significantly lowest enzyme activity of $33.80 \mathrm{mg} \mathrm{NH}_{4}-\mathrm{N} \mathrm{g}^{-1}$ soil $24 \mathrm{hr}^{-1}$ was found without application of any source of nutrients.

During the soybean pod formation stage the urease activity varied from 36.55 to $56.86 \mathrm{mg}$ $\mathrm{NH}_{4}-\mathrm{N} \mathrm{g}^{-1}$ soil $24 \mathrm{hr}^{-1}$. The highest activity was found with $100 \%$ P through NPS (56.86 mg $\mathrm{NH}_{4}-\mathrm{N} \quad \mathrm{g}^{-1}$ soil $24 \mathrm{hr}^{-1}$ ) which is statistically at par with application of $100 \% \mathrm{P}$ through PC (52.78 $\mathrm{mg} \mathrm{NH}_{4}-\mathrm{N} \mathrm{g}^{-1}$ soil $24 \mathrm{hr}^{-1}$ ).

Application of $25 \% \mathrm{P}$ through PC and NPS $50 \% \mathrm{P}$ through PC and NPS and 100\% RDF treated units were statistically at par with each other. Lowest Urease activity at pod formation was with control plot with $36.55 \mu$ mg $\mathrm{NH}_{4}-\mathrm{N} \mathrm{g}^{-1}$ soil $24 \mathrm{hr}^{-1}$ enzyme activity.
The improvement in organic matter status of soil which in turn was reflected by highest enzymatic activity similar findings were reported by Kachikerimath and Dhyan Singh (2001) and Thaware et al., (2016) where the application of organic source like crop residue stalk and organic manure showed highest urease enzyme activity than control.

Organics in form of enriched composts enhanced soil enzymatic activity with application of $100 \%, 50 \%$ and $25 \% \mathrm{P}$ through enriched composts along with chemical fertilizers. However significantly superior soil enzymatic activities at flowering and pod formation stages of soybean was observed with treatment of application of $100 \% \mathrm{P}$ through Nitrophospho-sulpho compost. The activities of various soil enzymes viz. Dehydrogenase, Alkaline Phosphatase, Aryl sulphatase, Urease increased in integrated use due to increase in organic carbon and microbial biomass owing to continuous addition of organics. Thus, the addition of organics under the integrated with inorganics maintained the organic matter levels in soil, thereby improving microbial status, enzyme activity and enhancement of population of beneficial microbes

\section{References}

Bedi, V. P., Dubey and N. Datt, 2009. Microbial properties under rice-wheat cropping sequence in acid Alfisol. J. Indian Soc. Soil Sci. 57(3): 373-377

Kachikerimath, M., and Dhyan Singh 2001. Soil organic matter and biological properties after 26 years of MaizeWheat- Cowpea cropping as affected by manure and fertilization in semiarid region of India. Agricultural ecosystem environment, 86:155-162.

Mandal, A., A.K Patra; D. Singh; A. Swarup and R. Ebhin Masto 2007. Effect of long term application pf manure and 
fertilizer on biological and Biochemical activities in soil during crop development stages. Bio-resource Technology, 98(18): 3585-3592

Miwa, T., Ceng CT, Fujisaki M, Toishi A., 1937. Comparative aspects of cycling of organic $\mathrm{C}, \mathrm{N}, \mathrm{S}$ and $\mathrm{P}$ through soil organic matter. Acta Pdhawahytochim (Tokyo) 10:155-170

Nannipiere, P., Muccini L, Ciardi C. 1983. Microbial biomass and enzyme activities: production and persistence. Soil Biol. Biochem 15:679-685

Panse, V.G., and P.V. Sukhatme, 1985. Statistical Methods for Agricultural workers. ICAR, New Delhi

Ross, D.J., 1971 some factors influencing the estimation of dehydrogenase activities of some soils under pasture. Soil Biol. Biochem, 3: 97-110

Tate, R.L., 1995. Soil microbiology. John Wiley, New York.

Thaware, V.G., S. G. Wankhade, S. P. Nandapure, S. M. Bhoyar and F. F. Khan 2016. Soil Enzyme activities as influenced by decomposition of crop residues in soil, PKV Res. J., 40(1): 3642

Vong, F.E., Vaidya P.H and V.V Gabhane 2003. Availability of nutrients in Vertisols as influenced by sorghumwheat cropping sequence. Journal of Soils and crops, 8(1): 70-72.

\section{How to cite this article:}

Ashay D. Souza, P. W. Deshmukh and Bhoyar, S.M. 2017. Effect of Enriched Composts on Rhizosphere Soil Enzymatic Activity of Soybean in Vertisols. Int.J.Curr.Microbiol.App.Sci. 6(10): 105-111. doi: https://doi.org/10.20546/ijcmas.2017.610.012 